\title{
Travel through Remote Terrains: Tibet in Focus
}

\author{
Kiron Susan Joseph Sebastine \\ MPhil Research Scholar, Dept. of English and Languages, Amrita Vishwa Vidyapeetham. \\ ORCID: 00oo-0002-0621-0303.Email: kiron.susan@gmail.com.
}

\begin{abstract}
As Ramana Maharshi a twentieth century mystic reflects, travel is not just physical journey from one place to another but also subliminal from one thought to another. The outer journey implies meaning only when it is accompanied by an inner journey. Travel writing incorporates everyday explorations along with cultural mappings, musings and meditations on the encounters experienced in the course of the travel. Travelling solo on an impulse; out of the natural curiosity that life brings, is the delight of living the journey. This paper does a comparative analysis of Nabaneeta Dev Sen's On A Truck Alone, To McMahon (2018) and Vikram Seth's From Heaven Lake: Travels Through Sinkiang and Tibet (1990). Both the authors journey through remote territories and terrains while maintaining their focus towards the Roof of The World, Tibet. While the aftermath of the Cultural Revolution in China occupies the centre stage in Seth's travelogue, the soreness of the Indo China War shrouds a permeable veil in Sen's work. The paper further explores the thin line between pleasure and adventure keeping in mind the gender binaries in travel writing. The human imagination is a no-man's land that encounters the prickles of political hostilities and the precarious suspicions of the state machinery. The human dimensions of the territorial borders annihilate the joys of travel as an experiment in freedom. Travel acknowledges the constant fluidity of the cognitive entities, the rejection of the familiar and the embrace of the unfamiliar.
\end{abstract}

Keywords: Travel writing, Subliminal, Cultural mappings, Self-writing, Freedom

\section{Introduction}

Travel can be related to any form of movement. Its very essence is about experiencing the unfamiliar and the unknown. Those who had the privilege of making journeys complimented it through their documentation. Writing and travel have been connected intimately and travel writing has evolved into a field of academic studies from its primitive stages as the pure documentation of a journey. The genre has taken the conceptual support of the disciplines such as literature, history, cosmography, geography, anthropology and ethnography in its metamorphosis into a major field of academic pursuits. There was a difference in the level of seriousness attributed to travel writing as it evolved into travel literature. Peter Hulme and Tim Youngs, in their Introduction to The Cambridge Companion To Travel Writing, states that travellers will usually follow their instincts and opportunities, rather than directions from home, and it is travellers' eccentricities and extravagances -in the literal sense of wandering offs -which have attracted many readers to the genre of travel writing (Hulme \& Youngs, 2002, p.5). They further mention that scholars working in the wake of Orientalism have begun to analyse the relationship between culture and power found in the settings, encounters and representations of travel texts (Hulme \& Youngs, 2002, p.8). Spontaneous journeys traverses through the considerably 'high friction' cultural as well as geographic landscapes and the traveller gets to

\footnotetext{
(C) AesthetixMS 2020. This Open Access article is published under a Creative Commons Attribution Non-Commercial 4.o International License (http://creativecommons.org/licenses/by-nc/4.o/), which permits non-commercial re-use, distribution, and reproduction in any medium, provided the original work is properly cited. For citation use the DOI. For commercial re-use, please contact editor@rupkatha.com.
} 
negotiate with the settings in a sequential or haphazard manner. The destination terrain being remote further increases the ambiguity quotient of the journey.

\section{Analysis}

The works taken for a comparative analysis in this paper are Nabaneeta Deb Sen's On A Truck Alone To McMahon (2018) English translation of Truckbahone McMahone, a well-known and humorous Bengali travelogue written by her way back in 1977 and Vikram Seth's From Heaven Lake: Travels Through Sinkiang And Tibet (1990). Sen's work is based on her unplanned journey from Jorhat in Assam all the way to the McMahon line at the Indo-Tibetan border. The travelogue narrates the details of her trip undertaken on an impulse and her encounters with the interesting individuals with whom she happens to share the space of her journey. From Heaven Lake: Travels Through Sinkiang and Tibet is a travelogue that had won the prestigious Thomas Cook Travel Book Award in the year 1983. It narrates the long journey Vikram Seth had made by road from China to India as a young research scholar. Hitch-hiking and walking, Seth travelled through Sinkiang and Tibet to Nepal and Delhi thereafter. The work is based on the journal notes and the photographs taken by Seth during the journey. Being a research scholar, Seth embarks on a sociopolitical comparison between China and India along with his journey. The aftermath of the Cultural Revolution in China has left its indelible imprints on the lives of the Chinese citizens. Seth is left surprised at the adaptability of the Chinese people as they set their lives into the compact and complex moulds prepared by their government. He has a keen eye for the details and draws out versatile as well as realistic images of the economic, geographic and cultural landscapes of China. In his foreword to the text, Seth mentions about these details as occasional ruminations although they stand out as incredible sources of information in his narrative. He does not forget to add a note of melancholy to his musings on the consequences of the Cultural Revolution. He writes:

On the hillside behind the temples are ruins of wood and clay. These reminders of the fury of cultural intolerance are so far beyond repair as to discourage even the thoughts of it. They have been left to the nettles and the occasional bright hoopoe; even the peach trees nearby, their small fruit green and diseased, have imbibed the bitterness of this place. Yet even here, painted on the rocks in a rainbow of colour, one can see the ever-present $\mathrm{Om}$ mani padme hum. (Seth, 2015, pp. 170-171)

Vikram Seth enjoys a position of great prominence in the arena of post 1980 Indian English literature and his works speak volumes of his unique creative insights, be it prose or poetry. Seth's travel narrative is dominated with male characters belonging to the working class from various cross sections of the Chinese society. The most prominent among them are a truck driver Sui, about thirty-five, whom Seth describes as alert-faced and a vigorous chain smoker, compact in limb and confident in manner who is accompanied by his fifteen-year old nephew Xiao San. The third passenger is a Tibetan named Gyanseng who is about twenty-five years old and is a man of very few words. These three men and their associations enrich the knowledge of Seth concerning the social scenario in China and Tibet. Seth does not forget to acknowledge them as travellers too; people who travel in the larger sense of the term, as a part of their livelihood. The journey to Tibet through Sinkiang ultimately evolved into a dream or rather an obsession for Seth. Carl Thompson, the editor of The Routledge Companion to Travel Writing raises a concern for which travel writing past and present is a vital resource and focus. He writes that the rise of a 'postcolonial' agenda and methodology across many disciplines has directed scholarly attention to how knowledge of other 
regions and societies is acquired and circulated along with the different forms of interaction and exchange that can exist between cultures (Thompson, 2016, p.17).

At this juncture, it is essential that we start examining the work by Nabaneeta Deb Sen, On A Truck Alone, To McMahon. The travel narrative presents itself in a very humorous and reflective manner with elaborate details on the author's encounters with myriad ordinary individuals and their reactions to a middle-aged woman's solo road trip in India way back in 1977. Deb Sen has adopted a very light-hearted approach throughout her narrative, and she has been able to add a fairy-tale charm to her whole travel experience. The fact that Deb Sen has authored several children's books strengthens this perspective as we analyse her travel narrative. The author has ensured that childlike joy and excitement flourish throughout her narrative. The text also identifies travel as an avenue of freedom and guarantees that the territorial as well as the cultural borders does not stand in the way of expressing travel as an experiment in liberation for any traveller. It is this 'freedom of expression' that associates travel writing to self-writing. Travel writing is indeed a form of self-writing. Susan Bassnett in her essay titled "Travel writing and gender" writes that the travel text as ethnography or social commentary transcends gender boundaries and increasingly in the twentieth century, male and female travellers have written self-reflexive texts that defy easy categorisation as autobiography, memoir, or travel account (Bassnett, 2002, p.225). Bassnett continues to write that the relationship between narratives of travel and some of the women travellers' search for identity is regarded as a problematic area of debate on women's travel writing (Bassnett, 2002, p.233). In the chapter titled "Beyond Reach" of the narrative, Deb Sen writes:

I wasn't really a free bird; I might not be chained, but I was still tethered to the rod. I may not have been caged, but I had to keep going back. That was where my food and water awaited me. And besides, even the free bird has a nest to return to, where its scarlet chicks were waiting with their beaks parted. Freedom is never guaranteed. (Sen, 2018, p.145)

The concept of 'a dream journey' is woven through the entire travel narrative just as it is in Seth's work. In Deb Sen's work, many a time the tone is similar to that of an excited and stubborn child and she doesn't have any qualms about revealing this. During her journey, while having a casual conversation with Mr. Subhashranjan Ghosh an agricultural officer, she makes it obvious. He mentions about a picnic to a blue lake, filled with swans through the Lhasa-Tawang Road and in response to this Deb Sen exclaims:

What! Really! 'I want to go, I want to go,' I demanded at once. When that didn't work, I tried even more intensely, saying, 'Let's go without telling anyone.' But still no luck. Unmoved, Subhashranjan said, 'You can't go at a moment's notice. You need permission.' Still, he was kind enough to take me for a drive along the dream road. A clean, broad, high-altitude road heading north-east towards the eternal mystery of Lhasa. And that was where it lay, beyond reach-the McMahon Line.(Deb Sen, 2018, p. 144)

This is in stark contrast to the very pragmatic and matured tone adopted by Vikram Seth in his narrative From Heaven Lake: Travels Through Sinkiang and Tibet. Seth too has been quite generous on humour throughout his narrative, but he accommodates it in a very subtle manner into his prose. In her essay Bassnett further mentions, "The fluidity and viscosity of the female body is contrasted with the linearity and solidity of the male body; while the latter results in a vision of the world that creates and controls a set of power relations, the former is less tangible, more flexible and infinitely varied" (Bassnett, 2002, p.230). This fact is brought to light in masculine and feminine narratives including travel narratives. 'Ecriture feminine,' a term coined by the French feminist Helen Cixous can be correlated to the self-writing by a female writer. 
Cixous presented the term in her essay titled “The Laugh of The Medusa”. Through her essay Cixous examined the major differences in language and text when the writer was a female. The term indicates the major role played by language in the understanding of the self. The multiple layers in the persona of a female writer are revealed for an examination to the readers when she creates a work. Travel narrative by a female traveller is not any different from this. Margret Atwood's The Handmaid's Tale explores a new manner of using the language to carry the weight of women's experiences. These forms of expression of the female can be identified as 'ecriture feminine'. The term refers to a particular style of writing and representation that emerged from a realization that the existing language systems are highly male oriented. It is inevitable that one may come across certain forms of women's language that are characterised by incoherence, disruptions and gaps. Critics might even attempt to evaluate women's language as incomprehensible and inconsistent. This difficulty of understanding the pure essence of women's language is attributed to the suppression and silencing faced by women for centuries which could be reflected in their writing. It is necessary that the narratives by women should be examined at the subliminal level as well. Women's writing has constantly been under the scrutinizing eyes of the patriarchy which imposes its norms upon the female identity of the writer. Female writers therefore persevere to indulge in detaching themselves from the various dimensions of these norms. They prefer to go to the extent of giving insights into the spiritual perspectives of themselves taking the necessary reinforcements from self-writing. Deb Sen writes in her narrative:

Whether it is joy or sorrow, life has been bountiful in handing me all its riches. I can now abdicate without any complaints. Those who have families often feel their fear of death is not for themselves. 'What will happen to my children if I die?' That is not what worries me. I am responsible for my children as long as I am alive. How does it matter to me once I am dead? He who gave me life will take care of this too. I am merely a tool in his hands. I have learned one very important lesson. Nothing is held up in anyone's life because of someone else. There is no such thing as 'indispensable' or 'unbearable loss to impede the flow of existence. If I were to disappear from the world today, no one's life will stop eventually. All losses will become bearable. (Deb Sen, 2018, p.166)

Deb Sen's journey to the McMahon line takes place at a time when she was going through a rough patch in her personal life. She was estranged from her husband and the journey ploughs out a channel through which she could let her emotions flow freely. What Vikram Seth regards as occasional ruminations abound in Deb Sen's narrative. These ruminations are sprinkled all over her travel narrative instead of being clustered together densely in certain areas as in the case of Seth's work. Seth comments in the tenth chapter:

I remember reading a question in an economics textbook: "If you were to be born tomorrow, would you prefer to be born in China or India?" If I could be guaranteed the lucky place in the Indian sweepstakes that I at present occupy, there is no question as to what my answer would be; even if I were poorer than the average Chinese child, I would still prefer to be in India. But if I were to be to the inhuman, dehumanising misery in which the poorest of third of our people live, to the squalor and despair and debility that is their life, my answer would not be the same. Man does not, of course, live by bread alone, but with so little of it he can hardly be said to live at all. (Seth,2015, p.129)

In an essay "The Art of the Contact Zone" Mary Louise Pratt, author of prominent critical works such as Imperial Eyes: Travel Writing and Transculturation and Toward a Speech Act Theory of Literary Discourse has studied what she calls the 'contact zones'- areas in which two or more cultures communicate and negotiate shared histories and power relations. She remarks that 
"contact zones are social spaces where cultures meet, clash and grapple with each other, often in contexts of highly asymmetrical relations of power, such as colonialism, slavery, or their aftermaths as they are lived out in many parts of the worlds today" (Pratt, 1999, p.2). As the traveller composes the narrative of travel, the everyday explorations along with cultural mappings, musings and meditations on the encounters experienced in the course of the travel are incorporated into the writing. It is interesting that quite often travel writing tries to associate with the socio-political scenario of the encountered territory all the while negotiating with the related constructs of 'home'. These associations and negotiations are integrated into travel writing without depriving it of the essence and the spirit of journey as a whole. It is not essential for a traveller to make his journey in accordance with a planned itinerary and many of them will usually take the liberty of following their instincts and opportunities. Readers have been attracted to travel writing owing to the eccentricities of the traveller and the impulsive travel patterns as well.

In his essay titled "Travelling to write(1940-200o)", Peter Hulme writes that most travel writing involves the experience of foreign cultures and languages, and some travel writers practice a kind of deep immersion in the cultures and languages, they are visiting, acquiring the sort of intimate knowledge which gives them access to people and places unknown to short stay travellers, let alone tourists.(Hulme, 2002, p.97) Both Deb Sen as well as Seth expresses the abovementioned traits in their narratives. The accessibility to an unknown cultural landscape that includes the language, is an essential element in the enrichment of travel writing. The eternal curiosity to experience the unfamiliar and to reach the ever-elusive Tibet is omnipresent in both their works. As a travel writer paints the picture of the journey, there are chances that the writer can often take up the role of a journalist. The writer strives to address certain serious issues that were encountered during the journey without losing the focus on the journey as well as the destination. Peter Hulme cites the example of the work Midnight In Sicily by Peter Robb who made an indigenous approach to narration with careful attention to gastronomy and painting by constantly looking at the larger cultural picture. (Hulme, 2002, p.98)

Seth's commitment to the social life of China can be assimilated through the fact that he was reasonably well versed in the Chinese language. Language does seem to have strong foothold in his narrative. This was quite a crucial element in Seth's triumphs over the hurdles thrown at him around every corner during his dream journey to Tibet. Conquering the terrain of communication itself forms an integral segment of any journey and this can be implemented with the help of creoles, pidgins or gestures. Seth describes in the most satirical fashion about the linguistic adventures of the Chinese in the English language too. He doesn't mince his words as he calls them 'language-rapists' from whose mechanisations one is never safe from. Seth further writes that these language-rapists merely use you as a punch bag for their language practice. In the avenue of travel writing, conquering the terrain of communication can be equated to a subplot within the main plot as observed in a work of fiction. A successful travel narrative emerges as the writer journeys through high friction spaces unscathed. According to Charles Forsdick, the author of the essay "Travel and the Body: Corporeality, Speed and Technology," the act of travel entails the body passing through places and spaces of varying degrees of familiarity, with the various forms of friction created between the travelling body and these places and spaces generating the raw material of what will eventually become the travel narrative(Forsdick, 2016, p.91). He further comments that travel itself has also customarily been understood, historically at least, as a profoundly corporeal experience, and the presence of the body in travel and travel writing - and the effects of different modes of travel on consciousness as well as on bodily and sensory perception - has been explored by a range of recent scholarship.(Forsdick, 2016,p.91) 


\section{Conclusion}

The aftermath of the Cultural Revolution in China, the scars of the Indo China War as well as the border issues between the two countries linger all along in both the narratives under analysis -On A Truck Alone To McMahon and From Heaven Lake: Travels Through Sinkiang And Tibet. Both the travels are focussed on Tibet and the travellers approach the destination from two different directions. The writers do not condemn the political scenario of disrupting their travel experience although their independent viewpoints blatantly glare at the readers. The perspectives of their travel narratives can further be positioned on the gender spectrum and examined. As Seth writes in the concluding chapter of his narrative, the best that can be hoped for on a national level is a respectful patience on either side is trying to solve the border problem, but on a personal level, to learn about another great culture is to enrich one's life, to understand one's own country better,

to feel more at home in the world, and indirectly to add to that reservoir of individual good will that may, generations from now, temper the cynical use of national power(Seth, 2015, p.221).

\section{References}

Bassnett, S. (2002). Travel writing and gender. In Hulme P., Tim Youngs (Eds). The Cambridge Companion To Travel Writing (pp.225-241). Cambridge University Press.

Deb Sen, N. (2018). On A Truck Alone To McMahon. Translated by Arunava Sinha. OxfordUniversity Press.

Forsdick, C. (2017). Travel and the Body: Corporeality, Speed and Technology. In Thompson, C. The Routledge Companion To Travel Writing (pp.91-101). Routledge.

Hulme, P. (2002). Travelling to Write (1940-2000) In Hulme P., Tim Youngs (Eds). The Cambridge Companion To Travel Writing (pp.87-101). Cambridge University Press.

Hulme, P., Tim Youngs (2002). Introduction. In Hulme, P., Tim Youngs (Eds). The Cambridge Companion To Travel Writing (pp.1-11). Cambridge University Press.

Pratt, M. L. (1999). Arts of the Contact Zone. In Bartholomae, D., Anthony Petroksky (Eds). Ways Of Reading. St. Martin's.

Seth, V. (1990). From Heaven Lake: Travels through Sinkiang and Tibet. Penguin Books India.

Thompson, C. (2017). Introduction. In Thompson, C. The Routledge Companion To Travel Writing (pp.1722). Routledge. 